\title{
UMA DISCUSSÃO COM PAOLO PRODI'
}

\author{
Adriano Prosperi \\ Professor da Scuola Normale Superiore di Pisa (Itália)
}

\begin{abstract}
Resumo
O artigo propõe uma crítica do livro de Paolo Prodi, recentemente traduzido para o português, Uma história da justiça. Alguns problemas são levantados, concernentes à compreensão da justiça como conjunto de normas mas também como ethos; ao conceito de revolução com o qual opera Prodi, e ao problema da ruptura e da continuidade; e ao lugar atribuído pelo autor à Inquisição moderna.
\end{abstract}

\section{Pallavras-chave}

Paolo Prodi: história da justiça $\bullet$ história da Igreja $\bullet$ formas constitucionais $\bullet$ intolerância.

\section{Abstract}

The article proposes a critical appraisal of Paolo Prodi's Una storia della giustizia, recently translated in Portuguese. Soma problems are evoked, concerning the notion of justice as a ensemble of rules as well as a ehtos; concerning the concept of revolution with which Paolo Prodi works, and the problem of rupture and continuity; and, finally, concerning the place given by the author to the modern Inquisition.

\section{Keywords}

Paolo Prodi: history of justice $\bullet$ Church's history $\bullet$ constitutional forms $\bullet$ intolerance.

\footnotetext{
${ }^{1}$ Resenha crítica do livro de PRODI, Paolo. Una storia della giustizia. Dal pluralismo dei fori al moderno dualismo tra coscienza e diritto. Bolonha: Il Mulino, 2000 (trad. port.: Uma história da justiça. Do pluralismo dos foros ao dualismo moderno entre consciência e direito. São Paulo: Martins Fontes, 2005), publicada em Storica, 17, ano VI, 2000, p. 85-100. Texto traduzido e publicado com a gentil permissão do autor, por Carlos Alberto de M. R. Zeron, professor do Departamento de História-FFLCH/USP.
} 
O livro de Paolo Prodi, Uma história da justiça. Do pluralismo dos foros ao moderno dualismo entre consciência e direito, é bastante excepcional no panorama da produção historiográfica à qual estamos habituados. É uma obra de pesquisa histórica realizada sobre fontes de primeira mão, mas é também uma interpretação de todo o percurso histórico da cultura ocidental sob o ângulo de um problema de grande e atualíssima importância: a questão da justiça, compreendida como conjunto de leis e de regras positivas capazes de restaurar a ordem social perturbada pelo crime, mas também como ethos, norma não escrita que fala no interior das consciências e consente individuar a culpa moral, o pecado. Sobre culpa, lei e memória fala-se e escreve-se difusamente; sobre isto escreveu recentemente, entre outros, Paul Ricoeur, propondo, entre outras coisas, pôr uma distinção preliminar entre culpa (culpabilité) política e culpa moral. ${ }^{2}$ Ao delito punido pela lei do Estado e à culpa moral são comumente reservadas histórias diversas: ao lado da história do direito como definição do crime, coloca-se a história do processo de justificação como evacuação do pecado. Não é fácil compreender o nexo entre uma coisa e outra, a fronteira móvel com que o curso da história uniu e distinguiu os dois campos. Em anos longínquos, foi o grande teólogo protestante Karl Barth quem colocou o problema da conexão entre justiça (Recht) e justificação (Rechtfertigung). Barth influenciou todo o pensamento teológico cristão nascido da crise dos anos trinta e da saída do totalitarismo nazista. Desde então, a questão da culpa, da lei e da memória gravou-se em nosso horizonte e colocou problemas ao trabalho histórico. Mas os produtos daquela proposta dividiram-se segundo as tendências profundas que separaram longamente mundo católico e mundo protestante. Da tradição historiográfica protestante resultou recentemente a publicação de uma história da "justiça de Deus" como doutrina teológica da justificação do pecador. ${ }^{3}$ Da tradição historiográfica do catolicismo italiano saiu, por outro lado, a proposta de Paolo Prodi de enfrentar, num mesmo quadro histórico, a história da justiça como conjunto que abraça pecados e crimes, sentido de culpa individual e demanda de justiça social. A sua pesquisa nasce da convicção de que há uma necessidade de voltar à história para buscar compreender a crise do sentido de justiça e o vazio moral no qual operam os tribunais. Há alguns anos, Duncan B.

\footnotetext{
${ }^{2}$ RICOEUR, Paul. La mémoire, l'histoire, l'oubli. Paris: Seuil, 2000.

${ }^{3}$ McGRATH, Alister E. Iustitia Dei. A history of the chrstian doctrine of justification. $1^{\text {a }}$ ed. New York: Cambridge University Press, 1986. (2a ed. 1998).
} 
Forrester, professor de teologia na Universidade de Edimburgo, defendeu que o problema da justiça consistia no ter-se tornado um mundo de regras a serem observadas, mais do que um compromisso pessoal para o bom andamento da comunidade. ${ }^{4}$ Para corrigir o erro, ele sugeria refletir sobre a história cristã e sobre a teologia: uma teologia que, tendo suas raízes na religião de um Deus injustamente condenado a morrer crucificado, não podia - pela sua natureza limitar-se a bendizer a ordem política existente.

Hoje, com a obra de Paolo Prodi, aquele auspício foi traduzido na realidade de uma pesquisa vasta, original, digna de atenta leitura e reflexão. Prodi é um mestre daquela historiografia, tão pouco em moda hoje, que busca no passado a formulação das questões oriundas do engajamento civil e político nos problemas do presente; um verdadeiro mestre, tão claro e determinado em expor nos seus livros as suas ideias quanto aberto ao confronto das ideias alheias e ao direito dos demais de seguirem a própria estrada. O seu percurso intelectual de estudioso é um modelo de constância e de inovação, nítido na sua lógica interna e capaz de abrir-se ao diálogo com grande liberdade intelectual. Não é o caso, aqui, de refazer o percurso que o conduziu dos interesses juvenis pela questão historiográfica que era então a da Reforma católica e/ou Contrarreforma, até a grande e original pesquisa sobre a história do juramento ${ }^{5}$ e sobre a história da justiça. Deve-se, ao contrário, discutir sobre este livro. É um livro que exigirá um longo tempo de absorção: a obrigação de discuti-lo séria e atentamente é tanto mais urgente quanto mais ameaça o perigo de uma celebração evasiva e distraída, como uma via de escape sem riscos diante de uma obra protegida e abrigada na espessura da pesquisa e na profundidade das raízes escondidas.

Ela apresenta-se com um título de enganosa modéstia. Mas o leitor encontra ali, além de “uma história da justiça”, muitas outras histórias: inclusive e sobretudo uma história da Igreja. Apenas, em lugar das mudanças de papas e cardeais, de conflitos doutrinais, de hereges e bruxas, aqui se oferece uma história de como foi construída, ao longo dos vários séculos, uma imponente realidade jurídica, moral, mas também política e religiosa, capaz de governar vastas massas humanas no plano espiritual e temporal. Por esta via, história da

\footnotetext{
${ }^{4}$ FORRESTER, Duncan B. Christian justice and public policy. Cambridge/ New York: Cambridge University Press, 1997, p. 47. Sobre o "vazio moral” (moral vacuum) no qual operam os tribunais, ver p. 38.

${ }^{5} \mathrm{O}$ autor refere-se aqui a outro livro de PRODI, Paolo. Il sacramento del potere: il giuramento politico nella storia costituzionale dell’Occidente. Bologna: Il Mulino, 1992 [n.d.t.].
} 
justiça e história da Igreja revelam o seu parentesco no passado histórico da tradição europeia ocidental.

No presente, o tema da justiça é sempre problemático e estimulante: a capacidade das instituições judiciárias e da cultura jurídica de responder adequadamente às questões de uma consciência perplexa encontra-se em discussão hoje mais do que nunca. O problema apresenta-se cada vez mais frequentemente, em diferentes ocasiões: hoje, chama-se condição do embrião, biogenética, "ventre de aluguel”; ontem e anteontem era a vez das clonagens, da ovelha Dolly, das doenças sexuais, da pedofilia e ainda outros. E havia ainda a privacy, a "igualdade de oportunidades”, o direito dos menores: a cada vez, problemas de regras a serem escritas, de autoridades especiais a serem criadas, de escolhas morais a serem julgadas e sancionadas pela lei. Mesmo os historiadores viram-se e continuam e ver-se cada vez mais frequentemente obrigados a elaborar seus códigos de deontologia profissional sobre questões gravíssimas - o "negacionismo", por exemplo - mas também sobre aquelas infinitamente menos graves (é recente o caso de uma proposta de código para o uso das fontes orais). Uma densa trama de normas legais é chamada a cobrir todos os atos da vida cotidiana, numa disputa infinita entre a rígida argamassa normativa das leis e as perplexidades da moral, ou antes, das diversas morais em conflito. É um processo de jurisdicionalização que substitui em modo progressivo e sistemático formas tradicionais de consenso difuso e de práticas extrajurídicas, inutilizando os últimos traços daquele espaço autônomo que a cultura do cristianismo europeu, herdeira da tradição jurídica romana e daquela religiosa do hebraísmo, reconheceu às questões morais. A raiz da conflituosidade repetidamente manifesta e da necessidade de acordar-se a cada vez sobre as questões, elaborando normas escritas como tratados entre potências em luta, reside na presença simultânea, na sociedade, de opiniões diversas e de escolhas morais que remetem a autoridades dessemelhantes e incompatíveis - autoridades coletivas tais como religiões e tradições, mas sempre e cada vez mais convicções amadurecidas na cela solitária onde o indivíduo fala consigo mesmo. Daqui deriva a natureza irremediavelmente problemática das relações entre moral e direito. $\mathrm{O}$ ato do juiz que estabelece que coisa é licita e que coisa é proibida aparece muitas vezes desoladamente arbitrário, como que pairando num espaço vazio, sem outro apoio a não ser aquele, precário, dos códigos. Pode-se ter esperança apenas na sua capacidade profissional de inclinar-se aos problemas das pessoas e da sociedade, de agir com prudência e discrição, de escapar do poder corruptor da mídia. Inclusive porque, no lugar 
das agências de moral social que lhe eram familiares - a religião e a política, as igrejas e os estados - avança hoje como protagonista um poder econômico transbordante e incontrolado, capaz de um uso sistemático e agressivo dos meios de comunicação de massa e, por esta via, novo legislador e construtor da moralidade coletiva, através do exercício de uma espécie de direção da consciência massificada. É este o cenário sobre o qual desemboca a reflexão de Prodi. As suas preocupações estão dirigidas a um aspecto do futuro que já se encontra inscrito no nosso presente. Hoje, as normas de leis já se inclinam sobre um terreno de escolhas morais individuais que vemos - frequentemente com um profundo incômodo - abrir-se ao sofisma, ao debate, à prática discursiva dos tribunais, à desenfreada e apressada subjetividade do ser humano que julga. $\mathrm{O}$ foro da consciência não possui uma voz coletiva; em tempos não longínquos, na Itália democrata-cristã do catolicismo de Estado, havia quem o interpretava referindo-se ao "senso comum” (por exemplo, do pudor). Mas, honestamente, não existiam modelos persuasivos naquela ocasião, nem tampouco passíveis de serem novamente propostos, hoje.

Este é o horizonte para quem se dispuser a ler esta história da justiça de Prodi, hoje: o precário, incerto horizonte do cotidiano. Buscar conforto e luz na história não é coisa que se faça sem risco. A historiografia - a italiana em particular - não vive um período brilhante. O muro de Berlim deixou sob seus escombros a certeza de muitos e fez emergir protagonistas de pouco fôlego, comprometidos no jogo fácil, mas, a longo termo, tedioso, que consiste em virar as certezas de cabeça para baixo e em rever os lugares comuns da perspectiva histórica. Mas as exceções são sempre possíveis; e esta o é. Aqui, finalmente, o leitor encontra um grande livro de história e de ideias, um livro que expõe minuciosamente o seu ofício de descobrir sob as moles ondulações da paisagem atual as duras sedimentações dos séculos. Dizer que é um livro importante é um risco de ser redutor diante da construção de grandes proporções da pesquisa, da importância das questões enfrentadas, da densidade das mensagens. Aqui temos o fruto mais maduro e rico de uma pesquisa histórica que, após ter explorado longamente a história e os problemas do mundo católico italiano, chega agora, pelos seus próprios caminhos, para um encontro que concerne em várias maneiras ao nosso tempo. A questão presente concerne à possibilidade de garantir-se - diz Prodi - “a sobrevivência da civilização jurídica ocidental, sem a presença de normas morais”, que são distintas e autônomas relativamente ao código. Não que tais normas não existam: mas a consciência individual parece 
a Prodi assustadoramente frágil e incerta, sem institutos, tradições, forças nas quais apoiar-se. A tendência de regular as questões de uma moralidade perplexa recorrendo a leis e juízes, tornando a inchar o código com normas sempre novas, parece um remédio inadequado e invariavelmente atrasado. O “código”, a resposta napoleônica adotada no Oitocentos pelos estados europeus, foi durante muito tempo a "moral dos povos", o lugar onde a crença no progresso depositou nas leis civis a razão natural enquanto fundamento do direito. O código substituiu o pluralismo dos ordenamentos do mundo medieval, deixando-o diante da simplificada oposição entre um direito inevitavelmente imbricado com o poder nas suas formas velhas e novas, e uma norma moral que não consegue mais encontrar um território exterior à consciência. Percorrer novamente, na sua longa duração, toda a história da justiça significa, portanto, duas coisas: de um lado, substituir uma história da antiga representação de uma luta de mão única entre razão e superstição, entre luzes e trevas; de outro lado - e isto é dito muito claramente -, significa excluir todo risco de nostalgia reacionária. O predomínio da lei positiva escrita e o seu monopólio por parte do Estado assinalaram um momento decisivo do processo de modernização. Diante da crise do Estado e da reproposição do dualismo entre consciência e lei positiva, a saída não pode ser aquela de voltar ao monopólio eclesiástico medieval da justiça; inclusive porque a Igreja que encarnou aquela antiga ordem encontra-se ela mesma diante de uma difícil encruzilhada, entre força de opinião e sociedade fundada sobre regras.

Ninguém deve enganar-se, portanto, com relação à aparente modéstia do título. Estamos aqui verdadeiramente diante de uma tentativa de escrever a história da justiça, no seu duplo aspecto: o sentido interior do mal e da culpa e a norma positiva para regular a vida social, a lei de Deus e aquela dos homens, a moral e a lei. É uma história, finalmente, de vastíssimo fôlego e, ao mesmo tempo, de realização atenta e artesanal, controlada e verificável nos detalhes. $\mathrm{O}$ projeto inteiro concerne à civilização europeia, dos gregos até hoje; mas, neste projeto, o que toma corpo, apoiado sobre a base de uma pesquisa de primeira mão, é, como já foi dito, a história da Igreja cristã ocidental. Aqui, a Igreja é, afinal de contas, uma realidade não mais dividida entre o plano do poder e aquele das ideias, entre os sentimentos dos crentes e as práticas do vértice. É história de uma pertença regida por regras, de uma realidade onde robustas instituições fundam e organizam a relação com Deus e com a sociedade. 
Em epígrafe, a lei dada aos hebreus por Moisés é citada junto à Antígona de Sófocles, a heroína destinada a morrer porque o deus que fala à consciência não tem lugar na polis grega. É um envio simbólico à tradição hebraica e ao direito romano, as duas entidades que presidem a construção do robusto palco jurisdicional da Igreja medieval. Mas é sobretudo o segundo que recita a parte do protagonista na reconstrução da nutrida pluralidade dos foros concebida pela cultura medieval e do modo pelo qual a estrutura e a cultura da Igreja deram a eles um fundamento orgânico. Infelizmente, o leitor deve amiúde dar crédito à densidade das páginas de Prodi, sem presumir poder controlar os seus movimentos em um modo analítico. Isso corre sobretudo ali onde a sua análise se detém nos caminhos medievais do direito, romano, canônico e "comum”, nos nexos e nas trajetórias entrecruzadas do direito civil e do direito canônico. O leitor que não tem familiaridade com a matéria fica frequentemente com a impressão de assistir a verdadeiras demonstrações de maestria, sem estar à altura de apreciá-las plenamente. Mas é culpa do leitor. É o sinal de uma abertura entre a história e o direito que pertence àquelas lacunas a serem preenchidas na formação dos historiadores, da qual certamente Prodi encontra-se indene. A incorporação de materiais jurídicos alentados em um painel histórico que não é de história do direito, em um sentido estreitamente disciplinar, é um mérito do autor. Aqui, o direito casado com a teologia fornece não apenas e não tanto a paisagem mental da época, mas o terreno vivo do qual as instituições retiram o seu húmus. O olhar plana sobre uma longa duração de séculos, a partir do observatório escolhido há algum tempo pela historiografia (sobretudo alemã) que retomou a tradição apontada por Max Weber: aquele das formas constitucionais e do modo pelo qual, de revolução em revolução, exprimem e modelam os ordenamentos da sociedade no tempo. Somos convidados assim a buscar na história do poder e da política, mais do que na economia, a força motora da história: e é em forma de Igreja, isto é, de um poder que se declara divino e não conhece limites, que o Estado entra em cena no Ocidente, como o escreveu Harold J. Berman em um livro bastante inovador, Direito e revolução. As origens da tradição jurídica ocidental, 1983. Na coleção de “textos e estudos", o volume de Prodi encontra-se ao lado da tradução italiana (não integral, mas “amplamente adaptada em função do público italiano”, conforme adverte o prefácio) do livro de Berman, e é provável que dali em diante encontremo-los associados como títulos gêmeos na literatura de referência. Queremos contribuir para que isto não ocorra sem qualquer discernimento. Que a obra secular 
(iniciada em 1938) de um professor emérito de Harvard formado na escola de historiadores do direito e da sociedade de cultura anglo-saxônica (os nomes citados são aqueles de E. Rosenstock-Huessy, T. F. T. Plucknett e R. H. Tawney) seja diferente, em muitos aspectos, daquela de um historiador italiano formado na Universidade Católica do Sagrado Coração, aluno de Giuseppe Dossetti, de Hubert Jedin e de Delio Cantimori, não poderá certamente causar estranheza. Prodi declara em mais de uma ocasião referir-se à obra de Berman e não há razão para duvidarmos disso. Basta o envio comum a Weber e a uma noção do direito como fato, mas sobretudo como ideia, como fenômeno material e ideal que nasce das estruturas e se difunde para cima e para baixo. Entre ambos, é possível notar uma preferência de Berman pela teologia e de Prodi pelo direito: Berman fala de uma "revolução teológica” (na divisão entre razão e fé) como uma companheira indispensável daquela jurídica. Mas é sobre o uso do conceito de “revolução”, mais em geral, que se nota uma diferença. Prodi declara apropriar-se de uma ideia capital da obra de Berman: que a primeira revolução ocidental foi a papal, iniciada por Gregório VII e completada por Inocêncio III e Bonifácio VIII. Mas já no modo como Prodi cita, parafraseando a obra de Berman, tem-se uma indicação do seu modo de interpretá-la: para ele, o volume de Berman “põe a 'revolução papal', a reforma iniciada por Gregório VII no século XI (...) na base do dinamismo constitucional que caracteriza toda a vida do Ocidente” (p. 60). A revolução torna-se uma reforma. As palavras são importantes no trabalho histórico; mas não é apenas questão de palavras. Para Berman, o conceito de revolução indica uma fratura violenta e profunda infligida pelo papado e pelo vértice da Igreja cristã na sistematização do poder real e das doutrinas - portanto, no plano real como no plano simbólico -, ali onde Prodi deixa de lado as “revoluções” nas doutrinas e acentua os aspectos de continuidade, ou ao menos o caráter de moto perpétuo de um processo de inovação que, de alguma maneira, compartilha a mesma natureza da síntese de romanidade jurídica e de fermento evangélico cristão que, no seu resultado e no seu influxo contínuo e recíproco, criaram o Ocidente. Por esta via, revolução acaba sendo quase o sinônimo de continuidade: “o que caracteriza o Ocidente e que qualifica a civilização como continuamente móvel e revolucionária-escreve na p. 112, ilustrando a sua leitura da proposta de Berman - é a dialética entre estas instituições, quais sejam o direito canônico e o direito secular, a Igreja e o Estado, em concorrência entre elas para normatizar a vida do homem”. Uma continuidade revolucionária, uma revolução contínua: o oximoro introduz uma 
visão organicista do desenvolvimento histórico, no lugar de uma ideia - aquela de Berman - dominada pela descontinuidade.

A diferença faz-se ainda mais evidente quando o discurso enfrenta um tema obrigatório de qualquer história da cultura jurídica europeia e do lugar que nela ocupam os direitos da consciência: a Inquisição contra a heresia. Este é o aspecto mais controverso da ação do papado medieval, aquele diante do qual a escolha oscila entre uma apologética medievalisante e nostálgica mais ou menos embaraçada e uma reivindicação mais ou menos apaixonada das conquistas das lutas religiosas do Quinhentos e da razão iluminista. Berman liberta-se rapidamente da questão: para ele, a presunção eclesiástica de julgar a heresia e de puni-la com a pena de morte foi a virada revolucionária realizada por uma hierarquia eclesiástica que, entre os séculos XI e XII, traçou pela primeira vez "uma nítida distinção entre pecado e crime” e "conseguiu retirar astuciosamente das autoridades laicas a jurisdição sobre os pecados” (p. 210). É lapidar o seu juízo sobre o assunto: para ele, o recurso à pena de morte para os heréticos representou uma "anomalia sobre a qual, ao final - no século dezesseis - encalhou todo o "modelo"” (p. 211). Em Prodi, o discurso é cheio de nuances: a inquisição eclesiástica sobre a heresia é uma necessária "fronteira externa” da ação da Igreja e um instrumento interno de disciplina, um instrumento "racional e formalizado" (p. 92), um progresso indubitável com respeito à era precedente, dos juízos de Deus, um ato de imposição da obediência à autoridade para quem a heresia é concebida sobretudo como desobediência ao poder legítimo. As suas raízes e suas copas encontram-se alhures, são atribuídas mais ao poder laico que àquele eclesiástico, mais à tradição romana que àquela cristã: "paradoxalmente, mas nem tanto - observa Prodi -, o procedimento inquisitorial é a parte do direito canônico mais dominada pelas normas do Corpus iuris civilis justiniano” (p. 97). E não por acaso as inovações de Inocêncio III vêm assinaladas como imediatamente assimiladas pela legislação anticlerical de Federico II. Quanto à nova Inquisição quinhentista, a romana, ela quase não contribui neste projeto entretanto vasto: ela é sumariamente julgada como um simples sobressalto daquela medieval. A cena da época é totalmente ocupada pelo conflito entre o Estado e a Igreja, em matéria de uso do poder sobre as consciências: é o Estado vitorioso que se ocupa da construção de um sistema disciplinar, apropriando-se e estendendo o plano elaborado pela Igreja nos séculos precedentes. A solução anglicana de substituição pura e simples do 
titular supremo do poder, sem alterações de outro gênero, é julgada exemplar. E o mundo católico italiano sai definitivamente de cena.

Tudo isto é bem compreensível, ainda que não totalmente e nem sempre compartilhável. O desenvolvimento histórico da Igreja católica, da Contrarreforma em diante, conduz ao receptáculo do Concílio Vaticano I e de um embastilhamento dentro dos confins de uma área - aquela italiana - longamente tutelada pelos riscos do mundo moderno, ao preço de um sistema fundado sobre a cenoura (a confissão) e o bastão (a Inquisição). Deter-se sobre um silêncio num livro tão denso e rico pode parecer pouco generoso. Uma certa dose de esquematismo é inevitável em um percurso tão certo e determinado no seu objetivo, de parte de quem não tem tempo para sobrestar-se em detalhes, porque tem em mente coisas mais importantes para dizer. Mas uma discussão de um livro importante como este deve colocar em primeiro plano os pontos de divergência para ser útil ao leitor e para corresponder à vontade explícita do autor de estimular as ideias. Seja dito então que, entretanto, a Inquisição medieval não foi apenas uma defesa nos confins do mundo cristão e não tinha modelos antigos que retomar. Como observou Arnaldo Momigliano, a intolerância nasce com o cristianismo medieval; o mundo antigo não a havia conhecido. Ora, a luxuriante profusão de literatura jurídica e de institutos que estruturam o espaço da lei moral e da relação com Deus está intrinsecamente ligada ao regime de cristandade como regime de intolerância. Este aspecto, da intolerância semeada pela Igreja cristã, não é tematizada aqui como deveria: inclusive porque não se tratou apenas de heresia cristã, mas da relação com os “outros”, os judeus, os muçulmanos. O sistema de penas e de tribunais descrito por Prodi teve uma função essencial nos processos de exclusão e deu vida a uma ainda mais grandiosa construção de identidades agressivas que marcam até hoje as características do Ocidente. Portanto, fazer nascer das instituições e da cultura do governo eclesiástico a instância da resposta ao senso de culpa e da justiça ofendida é alguma coisa que recorda a farmacopeia da medicina moderna, a qual em boa medida devia curar o mal que ela própria provocava.

Ter em conta a relação entre construção de identidades coletivas e processos de exclusão ou de agressões não é secundário, contudo, com relação ao problema central do qual se fala. A moralidade do corpo social em regime de cristandade foi elaborada, cresceu e encontrou as suas instituições e regras em um contexto de fechamento (na Europa assediada) e de exclusão dos “diversos”. E explodiu quando o corpo cristão dividiu-se internamente. Por isto, o problema da Inqui- 
sição não é secundário. De qualquer maneira, é difícil admitir que a Inquisição que renasce na Roma dos Quinhentos tenha sido apenas um sobressalto daquela medieval. As suas novidades institucionais, a sua complexa ação histórica, o exercício de um controle sistemático e capilar sobre as consciências através da obrigatoriedade do vínculo entre confissão e Inquisição, introduzido por Paulo IV em 1559, são dados de uma realidade nova, adequados a uma situação em que se destroçara completamente a base de formação de uma ideia comum de justiça. Se o fundamento institucional e a cultura jurídica retomam elementos precedentes, fazem-no em uma situação e com uma intenção profundamente diversas, no interior da relação entre uma Igreja católica ameaçada interna e externamente e o resto do mundo cristão europeu. Para o vínculo institucional e obrigatório entre confissão e Inquisição, eu usei um termo - "tribunais da consciência" - que Prodi explicitamente recusa tomar em consideração, concentrando sua atenção, por outro lado, sobre o modo pelo qual o Concílio de Trento operou com relação à teoria e à prática da confissão. Por este caminho, os elementos de continuidade resultam bastante mais evidentes do que aqueles "revolucionários”, de ruptura. Mas o fato de que a sociedade daquela época e dos tempos seguintes não foi governada por padres tridentinos, e sim pelo papado e pelas congregações romanas dominadas pelo Santo Ofício, é um dado aceito (e Prodi apresenta no seu livro uma grande quantidade de argumentos neste sentido). Na experiência histórica, as nuances dos decretos tridentinos contaram bem pouco; por outro lado, pesou bastante o ato de império papal que impôs o deslocamento obrigatório das confissões diante dos tribunais da Inquisição. Aquele ato significou instituir "tribunais da consciência", e não outro. Aqui, não é possível abrir-se a outras interpretações, e é oportuno explicitá-lo. É menos produtivo fazer emergir a polêmica deslocada para um detalhe em si totalmente insignificante. ${ }^{6} \mathrm{~A}$ isto eu gostaria de acrescentar uma consideração

\footnotetext{
${ }^{6}$ A recusa da expressão "tribunal da consciência” encontra-se formulada na p. 284. A divergência de Prodi, em confronto comigo, vem assinalada na p. 285, n. 20, mas apenas naquilo que concerne à interpretação da noção de “disciplina” no pensamento do polemista católico Eck. Na realidade, não há qualquer divergência. Como nota justamente Prodi, Johann Eck retoma a constituição do Concílio Lateranense IV no seu programa de um sistema de disciplina cristã. Definir a ideia de Eck como uma disciplina plena de nuances humanistas e antiquisantes (Tribunali della coscienza, p. 266 n.) era uma banal observação de leitura, à margem do seu tratado mais amplo sobre o assunto, De poenitentia et confessione, ao qual eu remetia e que contém muitas citações de Ovídio, Sêneca, Menandro e outros autores clássicos. Sobre a “disciplina” como instrumento de governo do povo, o mundo antigo podia ensinar coisas bem diversas, como o livro de Prodi o demonstra.
} 
que nasce da experiência de uma pesquisa cujos resultados Prodi faz-me a honra de considerar "fascinantes". Percorrendo as atas dos processos inquisitoriais e dos testemunhos espontâneos ativados pelo mecanismo da confissão subordinada à Inquisição, num fechamento do sistema que mostra toda a carga permeada de violência que pesa sobre as consciências, fiquei marcado pelos testemunhos que se podem recolher nos documentos inquisitoriais da percepção, da confissão e da inquisição. Indubitavelmente, os crentes fiaram-se plenamente em tais canais da justiça da Igreja; mas houve um número impreciso e seguramente vasto de rebeldes, ou ao menos de pessoas que sofreram o seu peso intolerável. O sistema, visto na sua prática, manifesta a degradação das normas jurídicas elaboradas e descritas com cristalina lucidez jurídica por canonistas e juristas em um acúmulo de casos desajustados, dolorosos, de um peso quotidiano e duro. Eis o que eu queria destacar a propósito da questão da "modernidade” da Inquisição, da sua inscrição em um horizonte de garantias jurídicas e assim por diante. O livro de Prodi alarga enormemente o discurso aberto há alguns anos por John Tedeschi de um modo concreto e cauteloso, mas ao mesmo tempo decidido: em ambos os casos, a fonte dominante é aquela das regras jurídicas, das instruções para confessores e para juízes. Todavia, se incorporarmos à documentação as camadas sociais mais baixas e questionarmos qual percepção tinham daquele mundo da justiça, encontramo-nos diante de uma imagem profundamente diversa.

Muitos problemas abrem-se aqui e será necessário que os estudos históricos esclareçam-nos. Antigo e sempre atual é, por exemplo, o problema das dimensões do dissenso e da dúvida na época da Reforma e da Contrarreforma. Como interpretar aquela paisagem de inimizades e hostilidades difusas nas paróquias pós-tridentinas que surge na recolha de dados das visitas pastorais? Que a sociedade do Antigo Regime tivesse nos mecanismos de aversão e na litigiosidade fácil uma característica fundamental, e que deste ponto de vista a paisagem moral fosse muito diversa da disciplinada e compacta sociedade moderna é quase um lugar comum historiográfico. Mas é verdade também que à hostilidade horizontal interna ao corpo social soma-se, após a Reforma e a Inquisição, uma hostilidade vertical potencial, uma oposição surda e silenciosa nos confrontos da religião oficial. A normativa medieval se abatia sobre uma população que vivia pela primeira vez a experiência das diversas interpretações do cristianismo em uma Europa devastada pelas guerras de religião. É possível, portanto, que, na prática de governo, fórmulas antigas cubram realidades completamente novas: se nas visitas pastorais se encontra um grande número 
de casos de não cumprimento do preceito pascal, devemos contentar-nos com a explicação oficial ("inimizade") ou não podemos imaginar também motivos inconfessáveis de divergência doutrinal?

Mas é inútil continuar a percorrer sempre este mesmo caminho. A pesquisa de Prodi coloca-se sobre um percurso diferente, com respeito àquele que fazia derivar a afirmação da liberdade de consciência da experiência dilacerante do dissenso. Não encontramos neste livro nem sequer o nome de Sebastiano Castellione; toda a matéria vem resumida em um parágrafo dedicado ao “cristianismo radical" e colocada rapidamente sob o signo das utopias terrificantes de seitas para as quais basta enviar à obra, decerto clássica, mas fundamentada em velhas pesquisas, de Ernst Troeltsch. O fato - é necessário recordá-lo continuamente - é que esta não é uma história da afirmação da ideia de tolerância ou da liberdade de consciência, mas uma história da justiça como norma que une a coletividade em torno de valores partilhados, sob o governo de instituições que espelham e interpretam a pluralidade dos níveis e dos contextos. No esboço de Prodi, a liberdade de consciência não concerne ao indivíduo, não é a afirmação heroica do indivíduo isolado, mas a condição de uma coletividade que deve ser colocada em condições de ter valores morais comuns e partilhados de tal maneira que não exijam a intervenção de leis escritas. Esta condição - eis a anamnese histórica - nasceu na Europa a partir da presença de uma polaridade de poderes. Daqui deriva o diagnóstico desesperado de um Estado presente, sem saída e sem nostalgia. O percurso que o conduziu até aqui é indagado não seguindo os sinais dos progressos da afirmação intelectual da consciência individual, do direito à heresia, mas aqueles dos ordenamentos jurídicos e das suas relações com o poder, de um lado, e com a coletividade, de outro. À genealogia da concepção moderna da inviolabilidade das consciências individuais dedicaram-se as pesquisas de estudiosos como Francesco Ruffini e Delio Cantimori (e de seus alunos) sobre os “heréticos” do Quinhentos: seus estudos iluminaram os traços residuais de quem, então, reagindo aos poderes da Igreja e do Estado, aliados no combate ao crimen lesae maiestatis, colocou os fundamentos dos direitos das consciências, de todos, através da paridade das crenças possíveis e da recusa da violência por motivos de convicção religiosa. Trata-se de uma historiografia bem conhecida e familiar ao autor: mas aquele caminho foi conscientemente abandonado, porque não foi estimado fértil de respostas ao problema aqui colocado. A época que vai da Reforma luterana aos nossos dias foi descrita pela historiografia liberal e filo-protestante, desde 
há algum tempo, como o percurso em direção à autonomia da consciência individual, não mais sujeita às imposições de nenhum tribunal externo. Era uma história que começava com a célebre resposta de Lutero a Carlos V: o vínculo interior do indivíduo com a palavra de Deus era mais forte do que qualquer autoridade terrena. Desaparecia assim o poder da Igreja. Mas - observa agora esta história que parte de um ponto de vista substancialmente e profundamente católico, sensível à norma moral como regra de comunidades inteiras, lugar de encontro entre exigências difusas, elaborações jurídicas, instituições -, não o substituía a autonomia moral do indivíduo e sim o poder do Estado, pronto para exigir um pertencimento sem nenhum limite. Apenas na luta entre Estado e Igreja ter-se-ia criado, portanto, o espaço para o desenvolvimento da consciência como expressão da responsabilidade moral, lugar de liberdade do indivíduo e, sobretudo, do corpo social.

A esta longa fase da história medieval e moderna da justiça, Prodi dedica capítulos densos de doutrina jurídica e teológica e, ao mesmo tempo, limpidamente organizados, que tornam o seu livro uma obra de referência fundamental. O quadro do processo de estruturação dos novos poderes no panorama europeu da idade moderna que é aqui oferecido é nítido e rico de ideias. Dele emergem os estados modernos e inclusive a Igreja de Roma que se organizou ela também como um Estado, ou procurou recuperar um poder supraestatal através das concordatas, somado a um prestígio de governo universalista. Com a Reforma protestante, o direito canônico e o sistema de tribunais eclesiásticos (das cortes episcopais à confissão) foram diversamente herdados e elaborados pelas igrejas europeias e pela cultura jurídica, filosófica e moral do mundo moderno, enquanto na Europa católica o direito canônico feneceu e desapareceu, substituído pelo direito pontifício. A Reforma protestante foi a tentativa, da parte do poder dos príncipes, de substituir-se ao papado: uma tentativa que, como foi dito, atinge a sua forma perfeita com a Igreja Anglicana. Segundo Prodi, não foi a reação das consciências cristãs contra o poder papal, mas o conflito entre poder eclesiástico e poder estatal que permitiu que se abrisse um espaço autônomo para as escolhas da consciência. A criação de uma "ética laica" emerge da reflexão de Montaigne sobre o fundo da desilusão histórica diante do objetivo concreto da administração estatal da justiça, diante do tribunal do "novo Estado teorizado por Jean Bodin” (p. 356).

Este é o quadro. Não seguiremos o autor adiante, na sua apaixonada pesquisa, da qual nasceu uma construção robusta e ricamente povoada, onde a tradição 
do pensamento político e jurídico do mundo europeu moderno é inteiramente percorrida, com a agressiva inquietação de quem busca as pistas de alguma coisa que já conhece. Citaremos um único exemplo, notável entre outros (e que sirva de alerta ao leitor não especialista), no restauro da leitura de Kant. Prodi assinala a existência no pensamento do filósofo "de uma sede de juízo ético-pública não coincidente com a jurisdição estatal” (p. 187). Entre a moral da consciência individual e o campo da lei estatal, restava, portanto, inclusive para o filósofo do individualismo moderno, este espaço da moralidade pública como espaço governado por um poder julgador.

Estabelecido que este é o terreno da pesquisa e da reconsideração do passado, bastará dizer que todo o livro se destaca admiravelmente no modo pelo qual o autor é capaz de enfrentar sem temor fatos capitais da história institucional e política, assim como da história cultural da tradição europeia, à luz de uma questão fortemente ancorada no presente, sem nostalgia pelo passado, sem respostas pré-confeccionadas para o futuro. Sem nostalgia: o passado de sociedades moralmente coesas nas quais um aperto de mãos valia mais do que um contrato escrito pode parecer desejável aos olhos de quem deve confiar rigidamente na norma do código e preparar-se à litigiosidade dos tribunais nas mínimas ocorrências da vida. Mas aquele aperto de mãos valia em uma sociedade fechada, hostil para os estrangeiros e para os diferentes: uma sociedade como aquela dos vilarejos italianos do Seiscentos que regulava, no âmbito fechado do confessionário, as matérias dos incestos e dos abusos sexuais que ocorriam entre as paredes domésticas, ou daquelas populações bávaras do século XX cuja moralidade, segundo o núncio pontifício, arriscava ser perturbada pela presença escandalosa das “tropas negras francesas”. ${ }^{7}$ Aquela sociedade fechada, refratária ao diverso, foi varrida e hoje estamos diante do problema de como reconstituir uma moralidade coletiva em condições de pluralismo e de multiculturalidade. E a resposta não pode ser uma receita reacionária, do tipo que vem hoje proposta instrumentalmente por movimentos políticos racistas. Prodi faz bem em tomar um momento para um “a parte” com o leitor, onde explica com límpida prosa que “a passagem do pluralismo dos ordenamentos típico do medievo ao moderno dualismo entre consciência e direito positivo exclui (...)

\footnotetext{
${ }^{7}$ A partir do relatório de Eugenio Pacelli, datado de 20 de abril de 1920, citado em Emma Fattorini, Germania e Santa Sede. Le nunziature di Pacelli tra la Grande guerra e la Repubblica di Weimar, Bolonha, 1992, p. 277-8.
} 
qualquer nostalgia por um retorno a um pluralismo das fontes do direito, mas coloca com urgência o problema da existência de planos diversos de normas (...). O problema que temos diante de nós não é aquele da recuperação de um mundo perdido, mas sim o da relação entre o direito, na sua relação inevitável com o poder (qualquer que seja a forma que ele esteja tomando, atualmente) e a norma moral, entre o forum fori e o forum poli não circunscrito unicamente ao território interior da consciência” (p. 437-8). Este é o problema: como resolvêlo, não cabe ao historiador dizê-lo.

Em um conto de Mark Twain, o protagonista consegue colocar as mãos sobre a sua consciência e despedaçá-la; deste momento em diante, leva uma vida pacífica e sem remorsos, entre um delito e outro. É uma fábula que bem se adapta ao quadro histórico desta vasta e complexa história da justiça. Sem retirar nada à amplitude do quadro desenhado e da sua carga inovadora num amplo território historiográfico e civil, dir-se-ia que a história do homem moderno, aqui descrita, assemelha-se à história narrada pelo escritor norte-americano. 